grey squirrel flourishes in Wales and other parts of Great Britain, and the British house sparrow is common in New Zealand. The exhibit at Cardiff is grouped around a model of the old Cardiff-registered cargo vessel Tredegar Hall and shows a striking series of insects, spiders, molluses, reptiles and other creatures accidentally landed at the chief seaports of South Wales from overseas.

\section{Ethionine and Plant Growth Systems}

IT has already been ascertained that ethionine is an antimetabolite of methionine and that it has growth stimulatory and morphogenetic effects on excised roots of tomato grown in sterile media. R. L. Lowther and W. G. Boll (Canad. J. Bot., 38, 437; 1960) have now reported on the effects of ethionine on six different plant growth systems, for example, growth of latcral buds on decapitated dwarf beans, the rooting of excised, etiolated bean hypocotyls, expansion of leaf disks, and so on. It was noted that the pretreatment of sections of etiolated pea shoots with manganese lowered or prevented the stimulatory effect of ethionine. A considerable amount of new observations on various growth effects is set out in some detail. According to the nature of the growth system, ethionine stimulates the effect of auxins or 'antiauxins'. Some relationships between the known effects of ethionine and theories of auxin action, and its possible significance as an inhibitor of adaptive enzyme synthesis, are indicated.

\section{Translations of Soviet Science into English}

The Israel Programme for Scientific Translations has been inaugurated to provide English translations of recent and important Russien books in all brenches of science. The programme was initiated by the National Science Foundation, Washington, which supports the programme and selects the material to be translated (Soviet Science in English Catalogue, 1960. Pp. 24. Jerusalem: Program for Science Translations, 1960). The first issue of a catalogue of works translated under this progremme lists books which will be available some time before December 1960. The books are photo-offset reproductions of originals typed on IBM electric typewriters and are usually bound in cloth boards with dust jackets.

\section{New Filmstrips}

To their series of natural-history filmstrips, Educational Productions, Ltd., of East Ardsley, Wakefield, Yorkshire, has added four more which will be well received by school-teachers. One contains a series of frames describing common plants and animals of the hedgerow and will be specially suitable for junior schools; a sccond is of the same type but takes its examples from woodlands. The third, "Flowers of the Marsh and Pool", is of more use for botany scholars in secondary schools and includes some of the rarer plants as well as the more common. The fourth strip contains some excellent photographs of British and foreign butterflies and is the forerunner of a similar strip which will deal with moths. Each strip is accompanied by explanatory teaching notes.

\section{Ramsay Memorial Fellowships}

The Ramsay Memorial Fellowships Trustees have made the following awards of new fellowships in chemistry for the year 1960-61 : Mr. Alan Bewick, a general fellowship at the University of Durham; a Glasgow Fellowship to Dr. D. G. Watson at the University of Cambridge ; a New Zealand Fellowship to Mr. G. A. Rodley at University College, London; Spanish Fellowships to Mr. José Carcía Contreras, Miss María Covadonga Rodríguez Pascual and Mr. Salvador Oliver Moscardó, all at Rothamsted Experimental Station; a United States Fellowship to $\mathrm{Mr}$. Herbert L. Strauss at the University of Oxford. The Trustees have renewed the following fellowships for the same year to: Dr. P. J. T. Tait (General Fellow ship) at the University of Aberdeen; Dr. W. G. Paterson (Canadian Fellowship) at the University of Oxford; Dr. T. Anno (Japanese Fellowship) at University College, London; Mr. F. Baltá Calleja (Spanish Fellowship) at the University of Bristol.

\section{Announcements}

Mr. N. Elson has joined Cossor Communications Co., Ltd., as technical director. Educated at Trinity College, Cambridge, Mr. Elson was employed during the Second World War at the Radar Research Development Establishment, Malvern (formerly the Air Defence Experimental Establishment, Christchurch), where he made notable contributions to the development of the wave-guide. Following a period of research on radio wave propagation at the Cavendish Laboratory and in New Zealand, Mr. Elson was engaged on work on guided weapon systems at, Ferranti, Ltd., and has been, for the past six years, in charge of the research and development activities of the Racal Engineering and Instrument Companies as chief scientist.

The Physics of Fluids, published by the American Institute of Physics, 335 East 45 Street, New York 17, N.Y., hitherto published bimonthly, will be published monthly, starting in 1961 with volume 4 . It is hoped by this means to speed up publication of research on the structure, statistical mechanics and general physies of gases, liquids, plasmas, and other fluids.

THE Chemical Society, London, has issued "Handbook for Chemical Society Authors" (Special Publication No. 14), 6s. to Fellows, $21 s$. to non-Fellows (post paid). Although primarily intended for authors preparing material for publication by the Chemical Society, the 224-page well-bound volume contains sections on nomenclature and symbols which are of general interest.

Messes. Johnson, Matthey and Co., Ltw., Hatton Garden, London, E.C.1, have issued a publication, "Products of the Rare Earth Group", recording the properties of the pure rare earth metals and their oxides. The firm can supply the metals in ingots, rods, and sometimes wires, in various states of purity at much lower cost than hitherto.

A confEREnce on Nuclear Physics is being arranged by the Institute of Physies and the Physical Society and will be held in the Department of Natural Philosophy, University of Glasgow, during September 14 and 15. Sessions will be devoted to electron and photon interactions with nuelei at energies below meson threshold; strange particle physics; interactions involving pi- and mu-mesons ; nuclear forces and interactions between lightest nuclei $(A<4)$; experimental techniques. The Rutherford Lecturo will be given by Prof. C. F. Powell during the meeting; he will speak on "Studies of Nuclear Disintegrations at Very High Fnergies". 